\title{
Economic Impact of Water Pollution on Agriculture and Rural Households
}

\author{
T. Sarathamani ${ }^{1}, K$. Govindarajalu ${ }^{2}$ and Divya.K.R ${ }^{3}$ \\ ${ }^{l}$ Department of Economics,Nirmala College,Coimbatore,Tamil Nadu \\ ${ }^{2}$ Department of Economics, Bharathiar University, Coimbatore \\ ${ }^{3}$ Department of Botany, Kongunadu Arts and Science College, Coimbatore
}

\begin{abstract}
The damage to land, river and groundwater is extensive and it has been caused by the industries of various types which in turn has led to an impoverishment of local villagers due to their consequent ill health and the degradation of their livelihood bases. Five villages which are very near to the industrial estate situated at Pollachi, Coimbatore district, Tamil Nadu viz; such as Makinampatti, Chinnampalayam, Chandrapuram, Unjavelampatti and Solapalayam have been selected for the study. The results of the study reports that he water bodies around the industrial area are highly polluted. The income - wise analysis showed that $66.92 \%$ of the respondents in the income group, Rs.5000-8000 and 44.92\% of respondents in the income group, Rs.800012000 are facing all the problems of drinking water pollution.
\end{abstract}

Keywords: Pollachi, income group, industrial estate, local villagers.

\section{Introduction}

About one third of the drinking water requirement of the world is obtained from surface sources like rivers, dams, lakes and canals (Jonnalagada and Mhere, 2001). But, these sources have served as best sinks for the discharge of domestic as well as industrial wastes (Das and Achary, 2003; Tukura et al., 2009). The geochemical composition of water and sediments is largely governed by the physicochemical characteristics of the depositional environment and associated natural biogeochemical processes such as diagenesis, adsorption/desorption on/from organic matter and precipitation/ dissolution of Fe/Mn oxyhydroxides (Solai et al., 2010).

The regular and periodic changes in the climate synchronized with season are ultimately reflected in the environment parameters also, which in turn have direct or indirect influence over planktonic population (Saravanakumar et al., 2008). Good water quality resources depends on a large number of physicochemical parameters and the magnitude and source of any pollution load; and to assess that, monitoring of these parameters is essential (Reddi et al., 1993).

Collecting information by personal interview with the people affected by pollution is most essential not only to know their health problems by pollution but also to know their economic status. The health risk is due to environmental pollution at the residents and farmers of Pollachi suburban city where the industrial estate has located.This study aims at to analyze the status of environmental degradation caused by industries and the level of disturbance caused by the pollution in terms of health hazards by making a survey in five villages situated in Pollachi region.

\section{Materials and Methods}

The simple random sampling method has been adopted in the present study in five selected villages which are very near to the industrial estate situated at Pollachi Viz;Makinampatti, Chinnampalayam, Chandrapuram, Unjavelampatti and Solapalayam. In total, 387 households are selected as sample, constituting 10 per cent of the total households.

\section{Data Collection}

The relevant data are collected from the respondents by employing a well structured interview schedule.

\section{Data Analysis}

The collected data were classified and tabulated with the help of computer programming; cross tabulation is also made on the basis of putting socio-economic variables with dependent variables. 


\section{Results and Discussion}

The data on the income-wise respondents views on effect of water pollution was clearly evaluated. It could be noted that more than two-third of the respondents in the income group, Rs. $5000-8000$ have frequent occurrence of dysentery and diarrhea in their households and majority of the respondents in the income group, Rs. 15000 and above $(40 \%)$ refered to the frequent occurrence of vomiting along with dysentery as a consequence of polluted drinking water in their area. The same view was also hold by the (32.69\%) respondents in the lowest income group in the study areas.

The computed chi-square value 260.5 is greater than the Table value at 1 per cent level of significance. Hence, there is a significant association between income of the respondents and their views on the effects of water pollution.

Table -1. Income - wise Respondent's view for Pollution of Drinking Water

\begin{tabular}{|c|c|c|c|c|c|}
\hline $\begin{array}{l}\text { Income } \\
\text { (Rs.) }\end{array}$ & $\begin{array}{l}\text { Discharge of chemicals into } \\
\text { water bodies and waste } \\
\text { Water }\end{array}$ & $\begin{array}{l}\text { Accumulation of } \\
\text { Solid waste around } \\
\text { bore wells }\end{array}$ & $\begin{array}{l}\text { Accumulation r of } \\
\text { garbage and sewage } \\
\text { around water sources }\end{array}$ & All & Total \\
\hline Upto 5000 & $24(46.15)$ & $8(15.38)$ & $5(9.62)$ & $15(28.85)$ & 52 \\
\hline $5000-8000$ & $8(6.15)$ & $13(10.00)$ & $22(16.92)$ & $87(66.92)$ & 130 \\
\hline $8000-12000$ & $31(26.27)$ & $16(13.56)$ & $18(15.25)$ & $53(44.92)$ & 118 \\
\hline $12000-15000$ & $15(28.85)$ & $13(25.00)$ & $7(13.46)$ & $17(32.69)$ & 52 \\
\hline 15000 and above & $14(40.00)$ & $6(17.14)$ & $7(20.00)$ & $8(22.86)$ & 35 \\
\hline Total & $92(23.77)$ & $56(14.47)$ & $59(15.25)$ & $180(46.51)$ & 387 \\
\hline
\end{tabular}

Figures in parentheses denote percentage

Chi-square Result

\begin{tabular}{|l|l|}
\hline Chi square Calculated value & 290.4 \\
\hline Degrees of freedom & 12 \\
\hline Chi square table value 1\% & 32.9 \\
\hline
\end{tabular}

Table 2 presents data on the caste-wise respondent's views on the effects of drinking water pollution on human well - being. It could be noted that out of the total 387 respondents, 48.32 per cent of them stated that frequent occurrence of dysentery and diarrhea as the consequence of water pollution. More than half of the respondents of most backward caste $(50.41 \%)$ and scheduled caste $(57.34 \%)$ refered these problems in their area.

Of the total respondents, 26.36 per cent of them stated that the frequent occurrence of vomiting and dysentery are the consequences of water pollution. 13.44 per cent of the respondents stated that occasional occurrence of jaundice and the rest, 11.89 per cent of the respondents felt the occasional occurrence of water prone disease as consequences of water pollution in their locality. The statistical analysis by chi-square results revealed that the computed chi-square value 62.86 is greater than the Table value at 1 per cent level of significance. Hence, the differences in terms of caste are statistically identified as significant with respect to respondents' views on the effect of water pollution.

Table - 2. Caste - wise Respondent's of views on effect of drinking water pollution in the study area.

\begin{tabular}{|c|c|c|c|c|c|}
\hline Caste Group & $\begin{array}{c}\text { Frequent } \\
\text { occurrence of } \\
\text { Dysentery and } \\
\text { Diarrhea } \\
\end{array}$ & $\begin{array}{c}\text { Frequent } \\
\text { occurrence of } \\
\text { Vomiting and } \\
\text { Dysentery } \\
\end{array}$ & $\begin{array}{c}\text { Occasional } \\
\text { jaundice and } \\
\text { cholera }\end{array}$ & $\begin{array}{c}\text { Occurrence of water } \\
\text { prone disease }\end{array}$ & Total \\
\hline Forward caste & $18(33.33)$ & $15(27.78)$ & $9(16.67)$ & $12(22.22)$ & 54 \\
\hline Backward caste & $26(37.68)$ & $18(26.09)$ & $12(17.39)$ & $13(18.84)$ & 69 \\
\hline Most Backward caste & $61(50.41)$ & $38(31.40)$ & $11(9.09)$ & $11(9.09)$ & 121 \\
\hline Scheduled caste & $82(57.34)$ & $31(21.68)$ & $20(13.99)$ & $10(6.99)$ & 143 \\
\hline Total & $187(48.32)$ & $102(26.36)$ & $52(13.44)$ & $46(11.89)$ & 387 \\
\hline
\end{tabular}

Figures in parentheses denote percentage

Chi-square Result

\begin{tabular}{|c|c|}
\hline Chi square Calculated value & 62.86 \\
\hline Degrees of freedom & 9 \\
\hline Chi square table value 1\% & 27.5 \\
\hline
\end{tabular}

Table 3 reveals the data on the occupation-wise respondents' views on the effects of drinking water pollution. More than 60 per cent of the respondents from wage labour category $(62.3 \%)$ suffer frequently with the problem of dysentery and diarrhea. A well over one third of the industrial employees (36.92\%) suffering from vomiting along with dysentery. Majority of the government employees suffer occasionally with water prone diseases due to drinking of polluted water. 
The chi-square test is applied for further discussion. The computed chi-square value 197.8 is greater than the Table value at 1 per cent level of significance. Therefore, the difference in occupational status is statistically identified as significant with respect to respondents' views on effects of water pollution.

Table - 3. Occupation - wise respondent's of views on effect of drinking water pollution in the study area

\begin{tabular}{|l|c|c|c|c|}
\hline Occupation & $\begin{array}{c}\text { Frequent } \\
\text { occurrence of } \\
\text { dysentery and } \\
\text { diarrhea }\end{array}$ & $\begin{array}{c}\text { Frequent } \\
\text { occurrence of } \\
\text { vomiting and } \\
\text { dysentery }\end{array}$ & $\begin{array}{c}\text { Occasional jaundice } \\
\text { and cholera }\end{array}$ & $\begin{array}{c}\text { Occurrence of water } \\
\text { prone disease }\end{array}$ \\
\hline Agriculture & $43(44.33)$ & $35(36.08)$ & $7(7.22)$ & $12(12.37)$ \\
\hline Business & $19(40.43)$ & $11(23.40)$ & $9(19.15)$ & $8(17.02)$ \\
\hline Govt. Employees & $23(41.07)$ & $11(19.64)$ & $11(19.64)$ & $11(19.64)$ \\
\hline Industrial Employees & $26(40.00)$ & $24(36.92)$ & $8(12.31)$ & 77 \\
\hline Wage Labour & $76(62.30)$ & $21(17.21)$ & $17(13.93)$ & 56 \\
\hline Total & $187(48.32)$ & $102(26.36)$ & $52(13.44)$ & $8(6.56)$ \\
\hline
\end{tabular}

Figures in parentheses denote percentage

VI. Chi-square Result

\begin{tabular}{|l|l|}
\hline Chi square Calculated value & 197.8 \\
\hline Degrees of freedom & 12 \\
\hline Chi square table value 1\% & 32.9 \\
\hline
\end{tabular}

The reason for low yield of crops in industrial region is attributed to the following facts: The effluents produced from the existing units in industrial areas are acidic or neutral. The total dissolved solid (TDS) content is high, in addition to the levels of total suspended solids, chemical oxygen demand, biological oxygen demand, chlorides and sulphates. Fluoride content is high in the effluents discharged from the chemical manufacturing units.

It is observed that in the absence of any facilities to deal with poisonous waste water or toxic wastes, companies have resorted to indiscriminate discharge of their wastes. Besides the direct deteriorative effect of the fertility of the land, such practices also poison the groundwater used for irrigation. Farmers in the region report that yields have plummeted even while costs of extracting water have increased because new or deeper borewells have to be dug as an alternative to the contaminated groundwater in the existing wells. Habitat loss and habitat degradation are also major reasons for worldwide biodiversity loss in ecosystems, and are caused by a multitude of anthropogenic disturbances (Allan and Flecker, 1993; Richter 1997). The threat of global climate change is pervasive across all of the Earth's ecosystems, and is also often cited as a major threat to biodiversity (Sala et al., 2000; Strayer and Dudgeon, 2010).

The ability of plants to absorb nutrients can be altered by changes in TDS. Discharge of effluents on land, as has been and continues to be the practice in many industries, alters the soil's organic matter content and hampers the ability of soil organisms to replenish the organic content. The waste water has affected the water springs, and therefore, agriculture. Coconut, mango and tamarind yields are affected right at the flowering stage due to pollution in the study areas. Farm workers complain of sores on their limbs because of contact with contaminated water and sludge. In addition, the persons working in fields close to factories are also facing the threat of injury due to gas leaks or other such mishaps.

\section{Conclusion}

The pollution crisis and the energy requirement are mere different sides of the same coin. Industries have polluted the adjoining villages in many ways. The pollutants discharged from the industry degrades the soil quality. The soil quantity is damaged and its results are in the form of loss of crop yield. The water bodies around the industrial area are highly polluted. Hence, it is suggested to develop alternative sources of water for irrigation. It could be mainly in the form of developing canal irrigation, proper utilization of available surface water and storing of surplus rain water by the ways of constructing irrigation tanks.

\section{Acknowledgement}

The authors are very much thankful to their concerned Management and Principal of Nirmala College, Coimbatore, to promote research activities so as to facilitate the Government of Tamil Nadu and to help local residents. 


\section{References}

[1]. Allan, J. and Flecker, A. (1993); Biodiversity conservation in running waters. Bioscience, Vol.43, No.1, (January 1993), pp. 32-43, ISSN 0006-3568.

[2]. Das, J., and Achary, B. B. (2003). Hydrology and assessment of lotic water quality in Cuttack City, India. Water Air Soil Pollut., 150: $163-175$.

[3]. Jonnalagada, S. B., and Mhere, G. (2001). Water quality of the river in the eastern highlands of Zimbabwe. Water Res., 35: 23712376.

[4]. Reddi, K. R., Jayaraju, N., Suriyakumar, I., and Sreenivas, K. (1993). Tidal flunctuation in relation in relation to certain physicochemical parameters in Swarnamukkhi river estuary, East Coast of India. Ind. J. Mar. Sci., 22: 223-234.

[5]. Richter, B. Braun, D.; Mendelson, M. \& Master L. (1997); Threats to imperiled freshwater fauna. Conservation Biology, Vol.11, No. 5, (October 1997), pp. 1081-1093, ISSN 0888- 8892.

[6]. Sala O., Chapin F., Armesto J., Berlow R., Bloomfield J., Dirzo R., Huber-Sanwald E., Huenneke L., Jackson R., Kinzig A., Leemans R., Lodge D., Mooney H., Oesterheld M., Poff N. Sykes M., Walker B., Walker M. \& Wall D. (2000). Global biodiversity scenarios for the year2100. Science, Vol.287, No.5459, (March 2000), pp. 1770-1774, ISSN 0036-8075.

[7]. Saravanakumar, A., Rajkumar, M., Sesh, J., and Thivakaran, G. A. (2008). Seasonal variations in physic-chemical characteristics of water, sediment and soil texture in arid zone mangrove of Kachchh-Gujarat. J. Environ. Biol., 29: 725-732.

[8]. Solai, A., Suresh, G. M., and Sriram, E. (2010). Implications of physical parameters and traceelements in surface water of Pondicherry, Bay of Bengal, South East Coast of India. Int. J. Environ. Sci., 1: 113-124.

[9]. Strayer D, Dudgeon D. (2010); Freshwater biodiversity conservation: recent progress and future challenges. Journal of the North American Benthological Society. 29:344-358.

[10]. Tukura, B. W., Kagbu, J. A., Gimba, C. E. (2009). Effects of pH and seasonal variations on dissolved andsuspended heavy metals in dam surface water. Chem. Class J., 6: 27-30. 